\title{
食品, 料理の栄養学的係数表現法に関する研究 (VII) Studies on Nutritional Coefficient of Food (Part VII)
}

\author{
栄養係数による蛋白価算出法と他法との比較 \\ The Simple Calculating Method of Protein Score by Nutrition \\ Coefficient of Food and the Comparison with Other Method \\ (昭 和 38 年 11 月 26 日受理)
}

藤 原 邦 達 福 原 貞 介
(Kunisato Fujiwara) (Teisuke Fukuhara)

\begin{abstract}
According to the new concept of Nutritional Coefficientification, the method of calculating protein score was concretely indicated. The method was compared with the method by Izumi and the characteristics were pointed out.
\end{abstract}

蛋白価の簡易算出法については昭和38年 4 月の本学会 大会で泉氏らが発表”を行ない，同時”に著者らも采㧔 係数を応用した方法について言及した。その後泉氏は臨 床栄養誌により詳細な報告いる行ない，他方われわれも 本会誌に「食品中アミノ酸量の係数表現法と侐白価の算 出法」についてて発表中した。

一般にある概念にもとつ’く数値の計算, 算出の方法が 迅速で簡便であるには次のことがいわれねばならない。

1. 概念を一定の単純な公式に誘導する。2. 汹, 表対照による。 3. ただし戍，表対照回数をできるだ け少なくする。4. 計算回数を少なくして重複をさけ る。 5 . 他の概念をる同時に認識できる算出系路を通

る。 6. 機械的代入，演算に適当である。

てこで本報では著者らの方法 (以後 $f_{A A x}$ 法と呼ぶ）と 泉氏の方法 (以後 $F_{x}$ 法と呼ぶ) の特徽を以上の観点か ら明らかにすることにした。

\section{蛋白価算出法の比較および考察}

1. $F_{x}$ 法と $f_{A A} x$ 法による些白価算出の順序 いま，たとえば，I 食品の $A$ グラムと II 食品の $B$ グラ 么からなる献立の舟白価を求める必要があるとき, 以上 つ 2 法では各々, 次の手順に従って來白価を求める。

\section{(1) $F_{x}$ 法}

（i）まず食品成分表により， $A ， B$ グラム中の蛋白 量量を算出し， $\left(A_{1}, B_{1}\right)$

(ii) その百分染 $A_{1} / A_{1}+B_{1}, B_{1} / A_{1}+B_{1}$ の\%を求め, $a, b)$

(iii) 次にいわゆる $F_{a}{ }^{3}$ 表と対照して， I， II 食品の $\nabla_{x}$ を知り, $\left(F_{a}, F_{b}\right)$ (iv）公式 $a F_{a}+b F_{b}+\cdots \cdots=P S$ に代入して䅖白価 相当值 $P S$ を求める。

(v) (iii) (iv) 操作を必須アミノ酸全部についてくり かえしPSの最小のものを蚉白価と決める。

(2) $f_{A A x}$ 法

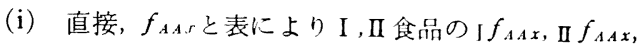
I $f_{\text {prot }}$, II $f_{\text {prot }}$ の数值を知る。

(ii)これを公式 $S_{A .1 x}=\frac{\sum f_{A A x}}{\sum f_{p r o 1}} \times K_{K N}$ に代入する。

但 L $\Sigma f_{A A x}=A \cdot \mathrm{I} f_{A A x}+B \cdot \Pi f_{A A X}$ $\Sigma f_{\text {prot }}=A \cdot \mathrm{I} f_{p r o t}+B \cdot \Pi f_{\text {prot }} \quad K_{K N}=17.3(N$ 倸数 6.25 のとき)

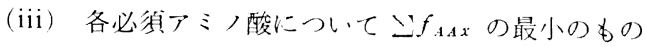
を見出し，これについての公式から $S_{A A x}$ 求めれば, それが值白価に相当する。

2. $F_{x}$ 法と $f_{A A x}$ 法の書きこ欢形式

(1) $F_{x}$ 法

まず各食品の岳白価\%を示す第 1 表（泉氏原著表 5 の

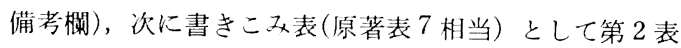
が必要である。

(2) $f_{A A x}$ 法

$f_{A A x}$ 法では值接第 3 表に記入する。

3. $f_{A A x}$ 法による算出の実例

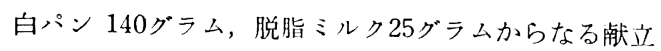
の蛋白価を求めよ。

まず $f_{A A x}$ 表から白パン, 脱脂ミルクに相当する优を 知り第 3 表に書き入れる。その結果は第 4 表に示したと おり 84 という相当値を得ることになる。 
第 1 表 $F_{x}$ 法その 1 表

\begin{tabular}{c|c|c|cc}
\hline 食品名 & $\begin{array}{c}\text { 1 人当り数量 } \\
\mathrm{g}\end{array}$ & $\begin{array}{c}\text { 蛋白質 } \\
\mathrm{g}\end{array}$ & $\begin{array}{c}\text { 蛋 } \\
\%\end{array}$ \\
\hline $\mathrm{I}$ & $A$ & $A_{1}$ & $a$ \\
$\mathrm{II}$ & $B$ & $B_{1}$ & $b$ \\
\hline
\end{tabular}

第 2 表 $F_{x}$ 法その 2 表

\begin{tabular}{c|c|c|c||c|c}
\hline Comp & $\mathrm{I}$ & $\mathrm{I}$ & $\cdots \cdots$ & $\sum_{a} F_{x}$ & $P S$ \\
\hline$x$ & $\times a$ & $\times b$ & $\cdots \cdots$ & & \\
\hline$t r y$. & $\mathrm{I} F_{\iota r y}$ & $\mathrm{I} F_{\iota r y}$ & $\cdots \cdots$ & & \\
\hline$S A A$. & $\mathrm{I} F_{S A A}$ & $\mathrm{II} F_{S A A}$ & $\ldots \ldots$ & $(M I N)$ & $(P S)$ \\
\hline$\vdots$ & $\vdots$ & $\vdots$ & & $\vdots$ & \\
\hline
\end{tabular}

第 3 表 $f_{A A x}$ 法の表示

\begin{tabular}{|c|c|c|c|c|}
\hline Comp & I & II & \multirow{3}{*}{$\mid \begin{array}{c}\sum f_{A A x} \\
\text { or } \\
\sum f_{p r o t}\end{array}$} & \multirow[t]{2}{*}{$S_{A A X}$} \\
\hline wt. & $\times A$ & $\times B$ & & \\
\hline prot. & I $f_{\text {prot }}$ & II $f_{\text {prot }}$ & & \\
\hline try. & I try & II $f_{\text {lry }}$ & & \\
\hline$S A A$ & $I f_{S A A}$ & II $f_{S A A}$ & $\|(M I N)$ & $\left(S_{A A X}\right)$ \\
\hline
\end{tabular}

第 4 表 $f_{A A x}$ 法の実例

\begin{tabular}{|c|c|c|c|c|}
\hline Comp & 白パン & スキムミルク & \multirow{2}{*}{$\begin{array}{l}\sum f_{\text {prot }} \\
\text { or } \\
\sum f_{A A x}\end{array}$} & \multirow[b]{2}{*}{$S_{A A x}$} \\
\hline wt. & $\times 140$ & $\times 25$ & & \\
\hline prot. & 12 & 51 & 30 & \\
\hline try. & 52 & 288 & (145) & (84) \\
\hline$S A A$ & 66 & 227 & 149 & \\
\hline & & & $\vdots$ & \\
\hline
\end{tabular}

(注) $\sum f_{A A x}$ の最小値145を $\sum f_{\text {prot }}=30$ で除し17.3 を乘じて84を得る。

4. $f_{A A x}$ 法の特致

（1） $F_{x}$ 法では食品成分表と $F_{x}$ 表の 2 表が必須である。 しかし $f_{A A x}$ 法では $f_{A A x}$ 表だけでたりる。従って $f_{A A x}$ 法では表対照の手間と煩雑さがはぶける。

（2）かりに $F_{x}$ 表中に飭品 $100 \mathrm{~g}$ 中の蛋白質グラム数の 欄を設け，食品成分表対照の必要をなくしても，F $F_{x}$ 法 では各食品の蛋白グラム数の算出打よびその\%比率 $(a$, $b$ ）の算出手数は除外できない。

(3) $f_{A A x}$ 法では $\Sigma f_{A A x}$, すなわちその献立にふくまれ るAAxなるアミノ酸の体重 $60 \mathrm{~kg}$ 成人男子の最小必要量4 との関係比率を第 3 表に抋いて判読することができる。 $\sum f_{\text {prot }}$ についても同様である。

(4) $f_{A \Delta x}$ 法では $A A x_{1}, A A x_{2}, A A x_{3} \cdots \cdots+$ よ゙の必須ア ミノ酸相互の栄盖学的な平衡関係か $\sum f_{A A x_{1}}: \sum f_{A A x_{2}}$ : $\sum f_{A A x_{3}} \cdots \cdots$ の数值として第 3 表の5えに直読できる。

(5) $f_{A A x}$ 法は計算回数の点でも蛋白質グラム数算出に はじまる $F_{x}$ 法と大差はない。

（6）精度も同程度である。

以上 $f_{A \Delta x}$ 法は $F_{x}$ 法よりも，より機械的，直接的かつ 応用性があるといえる。本来 $f_{A \Delta x}$ 法は食品, アミノ酸の 栄盖学的状態を示す采養係数論の一部として考案されて いるから，他の諸概念と関連があるのは当然である。

もちろん $F_{x}$ 法は次のよ5に書き直すことができる。

$$
\frac{1}{(A \mathrm{I}+\overline{B I})} \times\left(A I F_{a}+B \mathrm{I} F_{b}\right)=P S
$$

従って第 $1 ， 2$ 表をまとめて第 5 表のとおり記載する ことが可能である。

第 5 表 $F_{x}$ 法の変法

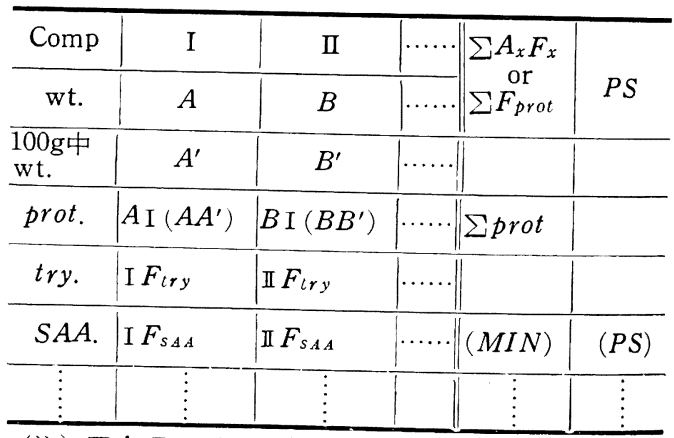

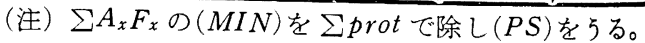
このばあい $A \mathrm{I}, B \mathrm{I}$ は各々 $A A^{\prime}, B B^{\prime}$ に相当する。 $A I F_{a}, B$ I $F_{b}$ の和を $\sum$ prot で除して $P S$ を求め る。この方法ではよほど単純化するが $f_{A A x}$ 法における 4 -(3), (4)項のよ5な特徴をあらわすことはできない。

結論

栄盖係数の概念にもとついて，蛋白価を算出する方法 を具体的に示し，泉氏の方法と比較してその特徴を明ら かにした。 $f_{A A x}$ 表を用いるわれわれの方法は迅速簡易 算出法としてょり大きい実用価値があるものと考える。

$$
\text { 文 }
$$

献

1) 泉, 片山: 栄盖と食糧, 16, 講演要旨 (1963)

2) 藤原, 福原 : 同上

3）泉：臨床栄養, Vol. 23, No. 1(1963)

4 ）藤原, 福原：栄養と食糧, 16,535 (1964)

（京都市衛生研究所） 